\title{
Churching Online: A Study on Religious Authority and Tourism in a Digital Age
}

\author{
Benson Rajan* and Devaleena Kundu†
}

\section{Abstract}

Christian churches in India with their growing access to digital technology have brought along promises to improve the interface between religion and society. This study looks at the Assemblies of God Fellowship (AGF), a popular youth church in Ahmedabad, Gujarat which has utilised the digital space to create an experience of engaging with the spiritual. This study contributes towards an ethnographically researched narrative of the church and its role in the domain of digital tourism, the manner in which religious authority negotiates the influx of the Internet. The research focusses on ways in which online communications shape religious meanings, identities, expressions of religiosity, and contemporary notions of tourism. AGF's inclusion of the online in its day-today faith practices along with its establishment of new units such as the 'media team' has led to the emergence of a media-savvy leadership.

Keywords: Online Religion, Digital Authority, Digital Tourism, Corporatisation of Church, Monitoring, Religious Identity

\section{Introduction}

Internet has become part of the communication media utilised by religious organisations. This approach has permeated into Indian

\footnotetext{
* School of Business Studies and Social Sciences (SBSSS), CHRIST (Deemed to be University), Bangalore, India;

benson.rajan@christuniversity.in † (SBSSS), CHRIST (Deemed to be University), Bangalore, India; devaleena.kundu@christuniversity.in
} 
religious institutions, especially the churches. Virtual connectivity has generated sites that have altered traditional religious practices, generating a gap between the institutional offline and the unconventional, online modes of religious practice (Baffelli, Reader \& Staemmler, 2011). The network's potential to spread content in virtual spaces like Facebook, WhatsApp, Twitter, YouTube, Instagram, and so forth, gives new platforms for expression, engagement, creation and exchange of thought (Fuchs, 2013). Therefore, virtual spaces have emerged for people to engage in meaningful discourses and exchange religious ideas. According to the KPMGFICCI report (2018), Internet has reached 481 million users in 2017. This has made India the second largest country in terms of Internet usage as well as access to internet infrastructure in urban spaces. The Digital India initiative (KPGM-FICCI, 2018) has brought religious institutions under its purview. The growing access to digital technologies in India has become a tool for proselytising.

This paper explores the dynamics of authority in offline and online communication practices along with an ethnographically informed discourse of modern trans-local dimension. It also looks at how authority is negotiated within the social structure of a church - Assemblies of God Fellowship, Ahmedabad. The authors assess communication practices that produce religious meaning and identity as well as maintain authority in a networked global space that transcends local boundaries.

\section{Literature Review}

The religious landscape in India is a combination of eclecticism and syncretism. Hinduism is the dominant religion in India with $79.8 \%$ (966 million) followers. Islam is the next largest denomination with $14.23 \%$ (173 million) followers. Christians make up $2.3 \%$ (27 million); Sikhs are a mere 1.7\% (20 million); Buddhist even fewer $0.7 \%$ (8 million); other faiths include Zoroastrianism, Judaism, indigenous tribal faiths and Sufi traditions (Census of India, 2011). These religions have negotiated with communication technologies, integrating them in the practices of their faith since the beginning of the Print era. 
Globalisation and India's economic progress have introduced pockets of modernity with World Wide Web connectivity. The multidimensionality and anticipated popularity of the Internet as a medium of communication has led to the setting up of websites by Churches in the latter half of the 2000s. These online contents develop meaning, by taking into consideration an individual's motivations, interests, cultural values, and sub-cultures within the meaning-making process. As a result, the growing access to such personalised data has empowered websites to become agents of religious advocacy (Baffelli, Reader \& Staemmler, 2011). Today, the Internet has become an instrument for religious self-realisation and a conservative space used by traditional religious institutions to preserve their existing structures and practices. The influx of the virtual into one's ubiquitous environment has brought forth new negotiations between religious authorities and individual religious journeys (Rajan \& Vaz, 2018). These dialectical encounters seek to shape the other and become the context for discovering religious practices that cater to niche religious values, religious cultural identities, and active faith expressions (White, 2007, Kenshin, 2011, Hiroyuki, 2011). The hype around religion in the digital space needs to be broken down and studied from its etymological base to understand the newfound reverence and obligations it has generated in the contemporary lives.

\subsection{Understanding Religion}

In Acts of Religion, Derrida (1998) explores the two possible etymological sources behind the word 'religion': religare, from ligare which suggested 'to tie or bind together'; and relegere, from legere, implying 'to harvest or gather' (Derrida, 1998, p.71). Together, the terms have come to denote the common foundations shared by a social group, including certain sets of regulations that draw forth voluntary compliance. Religion creates and seeks out cognitive consistencies that are structured through religious institutions or cultural history. The interaction between religious institutions and human actors recreates or establishes such cognitive structures which assist social behaviour (Stryker, 1980).

Religious actions bring forth various religious meanings because they involve a purposeful engagement with the sacred (Helland, 
2013). The active, purposeful engagement with the sacred reaffirms identity, regulates society, reduces anxiety, and brings about social cohesion. Religious rituals also provide space for individual and group activities as a representation of one's belief, which help cope with human limitations, by providing transcendental explanations or assistants when humans and science arrive at their analytical, physical, and moral limits (Geertz, 1993; Durkheim, 1995).

Religion, thus, needs to be studied through human actions. These actions involve online engagements with religious institutions that shape their social lives.

\subsection{Technology and Religion}

In the 21st century, due to growing digitisation of services and content and the reduction in the cost of technological innovations, the Internet has become ubiquitous. As a result, individuals live in an information-driven lifestyle. Consequently, the ease of consumption and participation in religious discourses has deterritorialised religion, making it increasingly mobile as a social institution. Therefore, participation in certain religious practices has become increasingly convenient and individualistic due to the personalised nature of online interactions. The digital presence of religious institutions provides participants with the option of experiencing the transcendent virtually, thereby, recreating the religious experience within the digital space.

According to Meyer (2006), religion and its practices burgeon with modernisation and development. Technological advancements have benefited several religious movements in the last decade. A popular example would be Sri Sri Ravi Shankar's Art of Living [2]. Digital modes of religious practices are witnessing a boom in modern times, marking themselves as outliers in the cohort of traditional religious institutions. The growing interaction between the Internet and religion can be understood through the distinction that Christopher Helland (2005) draws between 'online religion' and 'religion online'. According to Helland, 'religion online' provides religious knowledge without dialogic interactions. It functions like the official/traditional religious groups that follow hegemonic structures of top-down communication. On the other hand, 'online religion' aims at establishing the primacy of individ- 
ual faith and spirituality as well as providing ease of access and unrestricted freedom to the larger public. Within 'online religion', individuals who lack a sense of agency owing to their social status or identity can interact as equals, thereby confronting their social invisibility. However, 'online religion' too has its limitations; after a point, it succumbs to social life and reproduces traditional structures as reflected with religion online (Turner, 1969).

These traditional structures then shape the online environment thereby creating structures of power. As a result, the power roles ascribed to the religious authorities within the traditional setup permeates well into the digital space of the church.

\subsection{Religious Authority}

Religious authorities play a significant role in governance and establishing ideals for a given community to adhere to. They provide stability, cohesion, guidance, and continuity to the religious community. Not only do they draw behavioural boundaries for adhering to groups, but they are also responsible for imposing certain structures of authority on the community and establishing social norms. Additionally, they officially hold the power to interpret the sacred texts and guide communities towards their respective collective goals. These goals are created to shape the collective ambition and reward those who pursue it.

In order to function as a cohesive unit, there are different patterns of hierarchies, structures, practices, and rituals embedded in religious institutions. Authority is exercised and experienced through designated positions of power such as Priest, Prophet, Teacher, Counsellor, Guru, Apostle, Reformer, Bishop, Pope, and bodies such as councils, synods, presbyteries, elders, and so forth. However, authority belongs to the status group where individual followers of these authorities are expected to voluntarily comply with the status group's behaviour norms (Weber, 1968).

Authority figures also reward compliant individuals with social honours. The approval of the authority has significant social capital as it makes the compliant individuals dominant within their specified collective structure (Weber, 1968). The voluntary compliance towards any authority indicates that there is personal in- 
terest involved in obeying the authority. This relationship between the followers and leaders is continuous and establishes social order of subordination and domination that influences patterns of activity related to the institution. The legitimacy of subordination emerges from the subordinate's willingness to believe the claims of ascribed authority (Weber, 1968; Mauss, 2001).

In this regard, Weber's analysis of the three pure types of legitimate authority becomes significant. Weber distinguishes between legal/rational authority, traditional authority, and charismatic authority. While legal/ rational authority is witnessed through administratively established principles of governance wherein individuals exercise authority merely by virtue of holding a particular office, traditional authority is exercised when individuals gain legitimacy through inheritance, and their positions are bound by tradition. In contrast to both legal and traditional authorities, charismatic authority depends on the magnetism of the leader, who legitimises his leadership through "his heroism or his exemplary qualities so far as they fall within the scope of the individual's belief in his chari ma (Weber, 1968). Weber notes that "charisma" meaning "the gift of grace" is a concept that draws from early Christianity. Charismatic authority often reflects a sense of devotionality and sanctity towards the authority, generated from the leader's unique personality. The church as a religious community has both traditional as well as charismatic structures of authority before which members faithfully surrender in devotional reverence.

\subsection{Online Religious Authority}

A younger generation of priests and congregation members, tabled by the Internet, use the online as an innovative tool to attract and appeal to a diverse group of Internet users (Baffelli, Reader, \& Staemmler, 2011). Internet usage in the churches is a part of the development drive of modernisation in India. It began as a stateinitiated measure to bring the Internet to every part of India (National Telecom policy, 1994, New Telecom policy, 1999, \& National Telecom Policy, 2012). The Internet's alignment with the modernising agenda of the state has attributed authority to the Web.

The online environment provides authorities with new visibility generated by multi-modal resources available online (Baffelli et al., 
2011). It is also achieved through the quoting and replication of religious content. As and when such content gets circulated, it increases the visibility and reaches of the authority figure (Baffelli et al., 2011). Simultaneously, the online space also provides individuals or recipients with self-appointed authority if they utilise available resources for self-propagation. Opening up websites for religious institutions allows individuals to dictate communication practices. However, while traditional authorities can use their exclusive offline resources to establish themselves as online experts of their religious fields, their expertise is more likely to be challenged on such digital platforms by the audience. On digital platforms, an audience member can critique any given content, devoid of the pressures and regulations extended by social collectives they are a part of. Through debates and arguments, then, the audience can challenge and even undermine the authority projected by such charismatic leaders. However, there is a dialectic tension between the expression and counter expressions that defend such authorities.

Religious institutions can, with time, money, and a workforce, utilise these resources to maintain and enhance their online visibility. This can be heightened through optimising search engine finds, uploading content, updating pages, interacting with visitors on the site, incorporating feedback, and so forth. However, less affluent religious organisations might find themselves further marginalised within the online domain.

Against this background, the research will focus on a particular Christian institution, Assemblies of God Fellowship in Gujarat and study its use of the Internet as part of its attempts to maintain an online authority.

\section{Background to the Assemblies of God Fellowship (AGF)}

The Assembly of God Church in Ahmedabad began as a small assembly for the youth that has been meeting regularly since 1998 . Over a period of seven years, it has transformed into a close-knit community with four friends at its leadership (Pst. Samuel, personal communication, 16 August 2017). The church came into existence in the year 2000, when it tied up with Assemblies of God in 
India in 2003. The AGF comes under the jurisdiction of the Gujarat District of the Assemblies of God in North India and follows the global Assemblies of God's statement of faith.

The church today has six elders who alternately preach and share the gospel. The AGF is united under the mission statement "to continue the ministry of Jesus Christ by spreading the gospel, transforming lives, and nurturing leaders by becoming a contemporary community that displays Christ-like character, highest levels of creativity and compassion and care for people" (AGF website, 2017)[3]. In over a decade, the AGF has become one of the fastest growing Protestant churches in Gujarat, with a significant number of followers being religious converts.

The AGF is renowned in the Protestant circles for creating musical albums; it has created around 200 songs for its church. They launched three albums, the first one in 2006, the second in 2009, and the third in 2013. These albums have been not only disseminated across India using distribution networks such as Frontier and O.M. music but they have been also made available online. The AGF also utilises online platforms such as ReverbNation and PayPal to market their music. The church has a significant virtual presence on both Facebook as well as Twitter. This online presence is maintained by the church heads, Pst. George and Pst. Ben, who see it as a medium to connect the church and the youth. The church's Media Team-comprising Robin and Nobin, both programmers by profession - is responsible for the upkeep of its online assets which include website pages, members area, soul cafe, newsletters, online helpline, testimonials, guestbook, music and videos. Today, the church has over 300 members who engage with digital platforms as a space of religious expression.

This paper analyses the dynamics of religious communication by studying the role of the Internet as a communicative practice in the church. Online communicative practices in the religious space are associated with change and adaptation. The AGF is one of the most virtually active churches in Ahmedabad, from a listing of over 42 churches with an online presence. This paper contributes towards an ethnographically informed discourse about the church and its online communication in the expression of religiosity and 
in shaping Christian identity and providing space for digital tourism.

\section{Theoretical Framework and Methodology}

The current research falls within an interpretative paradigm. The investigation was conducted as a participant in the AGF church. This assisted in the understanding individuals' responses and their negotiations with the church's online presence. The time spent in the church helped in witnessing how the Internet played a role in shaping the social workings of the AGF community. This interpretative paradigm draws from the individual's subjective experiences as the meaning-making process to understand their social reality (Blanche \& Durrheim, 1999; Guba \& Lincoln, 1988). According to Deetz (1996), the interpretive paradigm understands religious phenomena through the meanings people assign to them. Within this paradigm, it is possible to lay emphasis on the nature of religious interactions taking place both online and offline. Interpretative paradigm having its roots in the philosophical traditions of hermeneutics and phenomenology would further aid us in contextualising the position of the AGF members as they negotiate between their online and offline religious living. This study, thus, looks at the entire meaning-making process to understand how members of the AGF engage with online religious content.

Participant observation is the base methodology of our fieldwork providing insights related to the AGF's live practices. This has helped us focus on the religious world-views of the participants and how such perspectives shape their use of technology to cater to their religious purposes. The authors conducted participant observation within the church and in 'Life Cell groups' [4]. Along with participant observation, the authors conducted in-depth interviews with various stakeholders, such as leadership and congregation members who have provided their understanding and practice of online communication. Other means of data collection include direct observation, casual conversations, in-depth unstructured interviews, semi-structured interviews, and questionnaires. 
Over the course of this research, the authors also assessed how online communication practices shape offline identities, meanings, expressions, and authority. The general content of the online discourse has been cited and discussed in this paper. The authors also conducted interviews with the AGF's Media Team, and with the priests who were involved in an advisory and decision-making capacity pertaining to the online communication practices. Confidentiality has been maintained in this research due to the security risks to the church members in Ahmedabad. Therefore, pseudonyms have been used in this write-up.

\section{Analysis}

\subsection{Church Membership: Pre \& Post Internet}

The church's membership, according to Pst. Samuel, largely constitutes of working professionals and a niche group of Christian Protestants, who are either first or second generation Christians brought up outside of their linguistic territories. This group of Christian Protestants comprises mostly members from SouthIndian states, such as Kerala and Tamil Nadu who are now settled and working in Gujarat. For this group--who had never fully engaged with or experienced their native cultures--to find their native languages being used and certain traditional practices prevalent in their native states being replicated in the church services they attended in Gujarat were reasons for a growing sense of detachment towards their faith. The pastor of the AGF stated, "With time I could see certain practices, which made me feel queasy and made me question the Church and its functioning" (Pst. Samuel, personal communication, August 16, 2017). The AGF provides services in English, Hindi and Gujarati (local language). A significant proportion of the members in the church come from outside Gujarat. The church mostly caters to college students, migrant workers and visitors. Before the rise of the Internet, the highest proportion of the church membership was from Ahmedabad, where people congregated through word-of-mouth. The Internet brought translocality to the AGF's membership through the church's digital content, which targeted and reached a diverse population. The AGF created an online religious space, which gradually legitimised and shaped social expressions of grief and online forums for extending 
their discussion on faith to a new medium for all to see. This created and continues to foster a culture of empathy among the members of the AGF. One of the members shared that,

"I was not a regular church goer and did not believe in any religion as such. One day when I lost someone very close to me, I came across a few members of AGF online and this forum helped me heal internally. Since then I joined this church and it gave me peace. (Daniel, personal communication, August 10, 2017)"

Members at the AGF are young, educated men and women with corporate jobs. They are attracted to the imaginations of Mega Churches ${ }^{[5]}$ whose modes of worship, preaching, use of state-of-art technology, and dynamic leadership is made available to the Indian audience through the digital platforms. The AGF attempts to cater to such audience desire by representing a modernised and corporate approach to Pentecostalism, an approach that takes into account the economic aspirations of its believers. Pst. Samuel discussed how most members requested to pray for their career. Here, the focus was on financial security and the idea of prosperity in their work life. He said, "God always rewards people for their faith" (Personal communication, August 16, 2017). The reward he is talking about is an economical reward which is grounded in the capitalistic aspirations of both the individual and the church.

The AGF membership application records details of one's virtual and physical life, such as name, date of birth, occupation, address, home phone, work phone, e-mail, mobile, marital status, date of marriage, churches previously attended, date of water baptism, date of Holy Spirit Baptism. Additionally, it requests details of one's family members, their relationship to the applicant and their birth dates. The AGF leadership then contacts the individual for an interview. The Membership Form states "following the successful completion of this interview you will be recommended for membership at the next fellowship meeting" (AGF Membership form, 2017, p.1). Widened access to technology has corporatised the church service through the usage of PowerPoint presentations for worship and during sermons. Meetings and reminders of events are communicated through the Internet and phone messages to the 
members. Internet technology has provided members to explore their religious faith beyond the church's immediate geographical borders. The website additionally provides an exclusive space for members, which is segregated into-all-women's space, executive member's space, administrative member's space, Pastor's wive's space, and other such clubbings. (Pst. George, Personal communication, September 22, 2017). Such spaces contribute towards bridging gaps and infusing a sense of togetherness into the group dynamics.

\subsection{Online Communicative Practices}

The growth of faith-oriented tweets, messages and posts have contributed to the creation of religious social capital (Cheong, 2012). Activities such as tweeting, blogging and posting often lead to an intermixing of the content generator's public and the private spheres for which these are ways to be linked with other believers, online users, and online digital resources. This mode of networking functions to disseminate sacred experiences, connect believers, find new audiences, thereby, creating an imagined body of social media users united by similar sentiments of faith (Rajan, 2016). The use of the Internet for church communication provides members with the opportunity to generate social capital in virtual spaces. The collective sharing of religious content on social media has a wide reach online (Rajan \& Sarkar, 2017), which generates collective social capital from like-minded Christians. The effect of such dissemination of religious discourse on social media causes the medium to flood with religious content, which then causes social media to proliferate a specific kind of religious discourse that leads to branding its affiliation to a religious order.

The increasing time spent on social media, along with regular exposure to the church's content, can enable deep consciousness of faith (Cheong, 2012), or, as some other scholars might suggest, can promote superficiality. Communicating through Internet technology becomes part of the church-building exercise that generates media-savvy leadership (Rajan, 2015). The leadership's communication practices in the institution's social media comprise uplifting content, Bible teaching, meditation content, inspiring videos and musical content. 


\subsection{Religious Shaping of Technology}

All six leaders of the AGF are administrators on the church's Facebook, Twitter and blogger accounts. The regular overlay of technology with religious discourse is an indication of the growing appropriation of technology in religious communication. The church leaders utilise social media to extend the conversation, propagate meaning, identity, authority, and tourism. Campbell (2010) refers to this social process as the religious social shaping of technology; it serves certain religious values and desires of the users. In the AGF, members are from different social and cultural backgrounds. One of the members discussed how during church, there is not much time left for further discussion on life and other aspects that one might want to share. She said,

“One day, my 5-year-old child asked me why his friend wears a turban and he does not. It is an innocent question and I wanted to share it with others and write an article on it. So, I did it on our AGF page for every member to read. I feel it is important that we have space outside the church to talk about our experience. (Sandra, personal communication, August 20, 2017)"

Online technology, thus, can be controlled and attuned with one's social life to provide access to devotional content that can be consumed in private and simultaneously be used for public forms of communication online.

The AGF as a church is very conscious of how their websites and blogs function. Every online post is carefully thought out. Few members shared how conversations within the physical space are oftentimes reflective of the online discourses. Tresa, one of the members of the AGF said, "Once someone who was a member of AGF wrote about a certain aspect of the functioning of the church in a negative light. It was immediately removed by the administrator and was dealt with in the church in the next meeting" (Tresa, personal communication, August 19, 2017).

Thus, socially cultured technology by religious communities, perform functions that affirm the community's cherished values in a virtual space. The AGF fosters online religion where members participate as producers and consumers online. The AGF's multime- 
dia initiatives have been a form of 'religion online' with evangelical mandates legitimising it. The church's online space involves a mutual shaping of religious practices and technology; practices of worship, rituals, teaching, discipleship, confession and testimonials are features of these virtual multimedia initiatives.

\subsection{Personalised Religion}

In order for people to accept the worldview of religion, they need to "do" the religion by living the way they live, interact and construct religious practices. The AGF's media initiative indicates a movement towards individualisation of religious practices. Individual access, self-regulated consumption and contribution, personalised content, emails, and membership spaces, are some initiatives that provide individual flexibility towards approaching church and religiosity.

Individual users regulate their religious practices to suit subjective needs, facilitating personalisation outside of the physical church. Many members shared the possibility of them requesting for prayers, support, and other forms of religious messages. For instance, one of the members said, "When my son was ill, I requested my church members to pray for his well-being. I still believe, it's the prayers, which healed him" (Mark, Personal communication, August 19, 2017). Information on the AGF's website prominently includes its inspiration, motto, certain testimonials, schedule of activities, and details of discussion forums, blogs, music, newsletter, and videos. Their website also has a cautionary role to play; it keeps the members informed about untoward incidents. This is important, given that the AGF is situated in Gujarat, a state which ever since the BJP's coming to power in 1998 has witnessed various instances of violence against religious minorities. With the Hindutva ideology gaining grounds in Gujarat--as evidenced during and post the 1998 Dang violence and the 2002 Godhra riots-religious minorities have increasingly felt the risks of communal violence.

Hebden (2011) discussed how during his visit to Ahmedabad in 2002, most Christians were shifting to safer and Christian majority ghettos. He further stated that the attacks on churches in 1998 and the sporadic violence led to the migration of Christians from the 
centre of the city to the south-west. Hence, most members recognised and embraced the role of such online spaces in informing members of any unforeseen situations. Daniel, one of the church members, shared, "[i]t is also a good platform for informing every member of the church to know what is happening around even when we are not physically close to each other" (Personal communication, August 10, 2017).

Moreover, according to Pst. George, the attempt has been to create a holistic online experience so that people who cannot be physically present are not deprived of experiencing the transcendent (Personal communication, September 22, 2017). The home page, with a pastoral buzz, videos and music, seeks to give multimediainitiated steps to go through worship, sermon, and dialoguing with the members virtually.

\subsection{Identity and Virtual Expressions}

Technology has often been equated with modernity (Campbell, 2010). This linking of modernity and digital life has also permeated into religious life. Today, the online networks provide audio and visual content of churches across the globe, eliciting shared statements of faith, spiritual movements, teachings and so forth, that transcend national boundaries of race, ethnicity, class and subcultures, generate a translocal religious identity. The growing use of technology by the AGF communicates a progressive and modern approach towards Christian identity that is anglicised, translocal, and progressive. The guiding principle of this identity is found in the AGF's statement of faith that proclaims itself a body of The Church Universal, "the holy society of believers in our Lord Jesus Christ, which he founded and in which he dwells by His Spirit" (AGF website, 2017). The Universal Church is an imagined community, which overlaps and competes with imagined national fellowships. The nation plays a significant role in generating collective religious identities within the global space, although aspiration for a translocal imagined identity is becoming prominent due to the Internet's role in religious communication.

According to members of the AGF, the major contribution of the church's social media pages is space for self-expression provided to the members of the congregation. The church's virtual space 
provides an opportunity for sharing testimonies (Fig 1.1), blogging (Fig 1.2 \& 1.3), filling in guest books (Fig 1.4) and discussing on forums (Fig 1.5), thereby, allowing freedom of expression and the confidence to converse in a safe, technology-enabled space. Internet generated spaces for religious expressions have enabled the AGF members to conveniently share their spiritual life and experiences with the community. In doing so, the individual is also in a position to establish one's identity within the local fellowship and its culture. The lack of centralised control, as seen in the catholic structures, has made the AGF belong to a translocal, imagined community of believers. Besides, the information once made available online can be stored for future reference, and hence, accessible at any point in time from anywhere, has also encouraged religious travel blogging.

\subsection{Religious Tourism}

The Internet is an open forum for individuals to share their travel experiences and interact with other travellers. The online exchange of first-hand narratives supports and influences travel-related decisions. Besides, such an exchange complemented by travel apps that are designed particularly for religious destinations invigorates the face of religious tourism. Religious tourism involves "sightseeing trips made with the intention of visiting places other than where people reside, work, satisfy their ordinary needs, and to fulfil their religious beliefs and see religious centres" (Garcia et al., 2018, p. 251). In "Regional Economic Effects and Marketing of Religious Tourism: The Case of Konya," the authors note,

[r] eligion is an important driver of the tourism industry not only for worship but for learning purposes. UNESCO reports that approximately 20 percent of the properties of the World Heritage List have some sort of religious or spiritual connection. Because some cultural heritage is connected with religion, a visit to an artistic/cultural site connected with a specific cult might easily become mediator of a religious experience. Tourists experience religious sites as learning experiences: The believer may learn something new about their own faith, and others have a chance to encounter cultures, life-styles, and human communities with 
their peculiar customs sand story. (Garcia et al., 2018, p. 253)

However, it is not always the actual physical experience of travelling to these sacred sites that is deemed significant. According to Lutz Kaelber, "the 'virtual gaze' is increasingly part of the consumption of postmodern religion in cyberspace" (Kaelber, $2006 \mathrm{p}$. 59). Several websites these days offer 'virtual guided tours' as well as 'self-guided virtual walks' of sacred places, undertakings that are validated by religious authorities. While such tours need not fulfill the human experience, a lot of tourists/pilgrims tend to opt for such virtual tours because they are risk-free, cost-effective, and comfortable. Simulating the experience of travel, however, is not an entirely new concept. As Kaelber observes,

[f]or those who could not afford travel to far-away places or considered it too cumbersome, spiritual theme parks such as the sacri monti in Italy were established in the later Middle Ages, to bring the foreign spiritual experience closer to home. In fact, the emerging concept of a "spiritual pilgrimage," for which travel and guide books provided instruction and guidance, created the possibility of seeking an entirely stationary way of traveling to holy places. (Kaelber, 2006, p. 50)

In today's post-modern world, predominated by the use of the Internet such as virtual, stationary modes of travel are increasingly gaining popularity. With a growing number of individuals turning towards virtual pilgrimage, religious institutions find themselves exploring the cyberspace to cater to such needs.

Moreover, religion is no longer a mere socio-cultural institution but also a brand. An increasing number of individuals approach their faith not just as believers but more significantly consumers. They expect "high quality religious services" in terms of the service, music, spiritual speakers, and access to places of worship (Usunier \& Stolz, 2016, p. 8). As a result, most religious congregations find it essential to market their spirituality. Destination marketing, for instance, has become essential as visitors to a sacred site expect their spiritual needs to be met vis-à-vis their consumerist 
demands such as good stay, the convenience of transport and communication, dining, and so on.

In fact, the domain of religious tourism has witnessed an increasing dependency on digital technologies to promote spiritual services and destinations, enabling what has now come to be known as 'faith branding'. As Mara Einstein notes,

[f]aith brands are spiritual products that have been given popular meaning and awareness through marketing. They have a readily recognizable name and logo, though there may or may not be a tagline. These products may be books, religious courses, a spiritual practice, a pastor, or some combination of all of these. (Einstein, 2008, p. 92)

Faith branding has become essential for the creation and continuation of religious identity. Globally, more and more religious organisations are making use of the digital platform to engage with their followers. The virtual platform becomes an extension of and an upgrade over the traditional way of engaging with the community. The online space allows religious organisations to not only promote their products but also provide their audience with easyto-access, bite-sized doses of spirituality in the form of thought for the day, snippets of sermons, songs, and so on. The audience is also kept informed of upcoming celebrations, and other community services, thereby, encouraging them to participate-either physically or virtually - and contribute towards such activities. For virtual participants, for instance, the online simulation of such events creates a sense of 'being physically present.' At times, such virtual participation can prove to be more rewarding since the individual can simultaneously partake of several events. Thus, in the face of fast-paced consumerist lifestyles, the use of digital technologies has determined, to a great extent, the success of religious experience and tourism, and it is in this context that the AGF's website and social media platform become relevant.

\subsection{Internet as an Evangelical Tool of Meaning Making}

Introduced in 2008, the AGF website and social media platform provide a new translocal dimension to the evangelical duties of the church. Through an investment of resources in the programming and media teams, the virtual space has generated an interactive 64 
website which replicates the workings of an actual church. For people who may migrate to other locations for employment and other purposes, the church's social media provides an opportunity to stay in touch and contribute digitally to the church and its community. The translocal member receives regular updates about the church's activities through images and videos posted on social media; they can consume the same devotional content that is preached by pastors on Pastoral Buzz for Today (Fig 1.8). Social media also expands the existing member base since a growing number of people make use of it to engage with devotional activity. Thus, with modernisation, growing urban penetration of Internet, and access to online church resources, devotional practices are becoming accessible beyond the physical church space.

At the AGF, social media is leveraged to create a bridge for users to remain connected at all times. The church's online approach is to transform the weak ties into stronger personal relations. This virtual relationship to real-life interpersonal attachments is reflected through church attendance and participation [6]. For instance, Pst. Samuel discussed how many people from different faith call him up to enquire about the AGF. He said, "I have had many people calling to enquire about AGF to join us since they like what we share and our ideology towards the world and our religious practices" (Personal communication, August 16, 2017). The initial outreach programs of the AGF relied on interpersonal engagements of its members with their neighbours and colleagues. Such programs were aimed at encouraging members and non-members in joining the celebrations at the church. Although the AGF strictly adheres to its statement of faith, which also espouses the proclamation of the Gospel to the world, its online forums of discussion have participants from across the globe. Topics discussed are, hence, in favour of those that are de-territorialised and translocal in nature. As a result, the virtual has given access to a diverse group of individuals beyond the confines of the church.

\subsection{Authority}

At the AGF, the six leadership members share administrative responsibility on the church's Facebook, Twitter and blogging accounts. They also have personal accounts on these social media 
platforms where they actively participate. They use social media tools to institutionalise their content, thereby providing their content credibility and religious authority.

The popularity and reach of social media have made the marketing of epiphany incredibly easier. In creatively marketing religious and spiritual experiences, the church builds on its social capital and status. The AGF employs copywriters and art directors who generate content; as a consequence, it markets itself and its activities in an attractive and contemporary way as compared to other Protestant churches. Technology's mediation with the church practices, as seen in the AGF, is reflective of the growing authority gained from the know-how of Internet technology, along with the knowledge of scriptures, which makes these intellectuals chief agents of mediatised translocal religion.

The shaping of technology and decision making in the virtual space is governed by the leadership who imports the culture from the physical church to the online space. This is done through digital architecture that communicates the need to keep the space holy and sacred. Therefore, the administrator constantly checks for offensive or disturbing content, because as participation increases so does vulgarity which the administrators need to manage (Pst. George, Personal communication, September 22, 2016). The AGF's social media is headed by Pst. George; the administration is headed by Pst. Ben along with Pst. Samuel, who administer the physical space and workings of the church as well. The constant surveillance of the website helps maintain the culture of the space and to do so, one needs adequate access to technology and scriptural knowledge, scholarship that the leadership possesses (Pst. Samuel, Personal communication, August 16, 2016). Interestingly though, these pastors while discussing the dissemination and regulation of online content repeatedly underscored the idea of surveillance. In their discourse, they constantly tried to justify why they needed to regulate what members posted on the church blogs and other church websites and social media pages. For instance, Pst. Samuel said, "Sometimes the question is that of whether it is a prayer or wishing something random. This is not to demean someone's wish but on a public forum, we have an image to uphold" (Personal communication, August 16, 2016). Thus, while posting a prayer 
request online is considered reflective of their religious faith, publishing any random wish on the website is perceived as diffusing the larger spiritual cause. Hence, access to technology as well as the content that is posted is monitored by the church leadership. According to Pst. George, this is because social media is "a bridging tool for us to reach out and assist people in their confusion" (Personal communication, September 22, 2016). The leadership approaches online users as people with lower spiritual and religious understanding; therefore, they view it as their duty to reach out and assist the confused masses.

Social media's content accumulates social capital for leadership. They utilise this capital to maintain their authority and direct the rest of the congregation towards their missions. The testimonials and guest book shared online glorifies the church; some people even share the fact that they copied the AGF's web content and tried to replicate similar programs in their churches. In the case of AFG, technology has helped maintain their status quo by reaffirming the authority of the leaders' in the virtual domain. In fact, the authority exhibited in the digital platforms re-legitimises the offline authority of these leaders. The authority of the leaders, as well as the translocal impact that the AGF's web content has, can be evident from some of the guest book quotes as shown in Fig 1.9.

\section{Conclusion}

The popularly held notion is that the virtual world is disjunct from the offline world. Through the examination of online and offline communication practices, the paper has tried to unravel the intertwining of the virtual and offline religious involvements of the church. Those holding the regulatory positions within the church use and shape technology to serve and corroborate the existing ideologies and structures of the church. The AGF's use of online platforms, therefore, is an attempt at reaching out to the existing followers and building new relations for the purpose of practicing and proliferating faith. In the case of the AGF, the article observed how the offline authority remains intact despite the increasing emphasis on building an online presence of the church. Its structure of authority in the virtual world is similar to and dependent on 
how it functions in the physical world. Hence, technology helps maintain the AGF's status quo by reaffirming the leader's positions of authority and legitimising it through shared digital content. Moreover, the AGF, through virtual representation, also shapes identities and realities of its faith content consumers who share a strong affiliation with the church.

The Twitter account, the Facebook page, and the two websites require regulation and supervision to embody a sacred culture. Feedback from the AGF's members emphasised that independence from censorship is necessary to maintain relevance in changing times. The adaptation of the AGF content within the online space and the replication of this model in other churches reflects the amalgamation of online and offline religious spaces. It is a testament to the religious leadership success in balancing and maintaining religious practices online, connecting the members with divinity and foregrounding a sense of community. The Internet's major contribution to the AGF has been the element of translocal participation, which enables the continuity of church life and its structure beyond the church's geographical limitations. The Internet has helped mirror the offline way of being, in terms of performance of religion and the value system attached to it.

Drawing from the participant observation of the AGF group and the analysis of the online discourse, this paper shows how the physical structure of authority and power resonates within the online domain. The paper also highlights how the online platform, as seen in the case of the AGF, helps propagate religious beliefs, endorse religious performance, and contributes towards digital tourism. The analysis contributes to the existing scholarship of the social construction of technology and the emerging research on understanding the nature of religion, both online and offline. The analysis also highlights how technology is used by the religious leaders to propagate their value system as it exists in the social environment. Even though social media has created a new architecture for participation, it is to a great extent bound by surveillance. In saying this, it is not negated that members of the AGF are entirely redefining the religious practices, values and beliefs. However, the point the article tried to make through the analysis using the interviews and participant observation is that all these negotia- 
tions and repositions are still firmly based on the offline space of religious ideas and beliefs.

\section{References}

Aaron, S., \& Lumsdaine, D. H. (2009). Emulating Azariah: evangelicals and social change in the Dangs. Evangelical Christianity and democracy in Asia, 87-130.

Aceval, H. (2009). Disturbed authority: tracing Shugendo's En-no Gyoja in Mixi, Facebook and Myspace. Paper presented at the Religion 2.0 in Japan: Shifting Patterns of Authority workshop, University of Tubingen.

Álvarez-García, J., Rama, M. C. R., \& Gómez-Ullate, M. (2018). Handbook of research on socio-economic impacts of religious tourism and pilgrimage. IGI Global, USA.

Baffelli, E, Reader, I., \& Staemmler, B. (2011). Japanese religions on the Internet: innovation, representation, and authority. Routledge, Abingdon.

Bendix, R. (1977). Max Weber: an intellectual portrait. University of California Press, California.

Campbell, H. (2010). When religion meets new media. Routledge, New York.

Census of India. (2011). Retrieved from http://www.censusindia.gov.in/ 2011census/C-01.html

Cheong, P. H. (2012). Twitter of faith: understanding social media networking and microblogging rituals as religious practices. In P. H. Cheong, P. Fischer-Nielsen, P. S. Gelfgren \& C. Ess (Eds.), Digital religion, social media and culture: perspectives, practices, futuresi (pp. 191206). Peter Lang, New York.

Cooke, P. (2008). Branding faith: why some Churches and non-profits impact cultures and others don't. Regal, California.

Derrida, J. (1998). Faith and knowledge: the two sources of religion at the limits of reason alone. In J. Derrida \& G. Vattimo (Eds.), Religion, Polity. Cambridge.

Durkhiem, E. (1995). The elementary forms of religious life (K. E. Fields, Trans.). Free Press, New York.

Einstein, M. (2007). Brands of faith: marketing religion in a commercial age. Routledge.

Fuchs, C. (2013). Social media: A critical introduction. Sage, New Delhi.

Frykenberg, E. R. (2008). Christianity in India: from beginnings to the present. Oxford University Press, New York.

Geertz, C. (1993). The interpretation of cultures: selected essays. Fontana Press, London.

Guba, E. G., \& Lincoln, Y. S. (1988). Do inquiry paradigms imply inquiry methodologies? In D. M. Fetterman (Ed.), Qualitative approaches to 
evaluation in education: The silent scientific revolution (pp. 89-115). Praeger, London.

Hebden, K. (2011). Dalit theology and Christian anarchism. Ashgate, Cornwall, UK.

Helland, C. (2013). Religion. In H. Campbell (Ed.), Digital religion: understanding religious practice in new media worlds (pp. 104-118). Routledge, New York,.

Hiroyuki, K. (2011). Preserving the dignity of Shinto Shrines in the age of the internet: a social context analysis. In E. Baffelli, I. Reader, \& B. Staemmler (ed.), Japanese religions on the internet: innovation, representation, and authority (pp. 62-80). Routledge, New York.

The Hindu. (2014, November 19). Internet users in India cross 300 mn. http://www.thehindu.com/sci-tech/technology/internet/india-setto-become-secondlargest-internet-market-by-decemberendreport/article6614417.ece

Internet Society. (2014). Global Internet Report 2014. http:// www.internetsociety.org/ map/global-internet-report/?gclid $=\mathrm{CM}$ 3u2Nm3iMACFUosvQodCqsAWQ

Jones, A. (2012). Christianity in South Asia: negotiating religious pluralism. In C. E. Farhadian (Ed.), Introducing world Christianity (pp. 65-77). Wiley-Blackwell, Oxford.

Jorgensen, D. L. (1999). Participant observation. Sage, London.

Kaelber, L. (2006). Paradigms of travel: from religious pilgrimage to postmodern tourism. In D. Timothy, D. Olsen (Eds.), Tourism, religion, and spiritual journeys (pp. 49-63). Routledge, London.

Kant, I. (1960). Religion within the limits of pure reason. Harper \& Row, New York.

Kenshin, F. (2011). The situation of Japanese traditional Buddhism in the Web2.0 Era: who attacks and who guards the religion? In E. Baffelli, I. Reader \& B. Staemmler (Ed.), Japanese religions on the internet: innovation, representation, and authority (pp 39-62). Routledge, New York.

KPMG-FICCI. (2018). Reimagining India's MEE sector. Retrieved from http:/ / ficci.in/spdocument/22949/FICCI-study1-frames-2018.pdf

Malinowski, B. (1954). Magic, science and religion and other essays, Doubleday, Garden City.

Meyer, B. (2006). Religious sensations: why media, aesthetics and power matter in the study of contemporary religion. Retrieved from https:// www.researchgate.net/publication/241889837_Religious_Sensations _Why_Media_Aesthetics_and_Power_Matter_in_the_Study_of_Cont emporary_Religion

Muller, M. F. (1910). Lectures on the origin and growth of religion. Scribner, New York.

Mauss, M. (2001). A General theory of magic. Routledge, New York. 
Nayan, D. (2008, January 14). An all-Christian village in Gujarat [India]. The Times of India. Retrieved from http:// search.proquest.com. ezproxy.auckland.ac.nz/docview $/ 428290305$ ?accountid $=8424$

Pathak, B. (2011, December 21). Gujarat's oldest Church in city [Vadodara]. Times of India. Retrieved from http:// search.proquest.com. ezproxy.auckland.ac.nz/docview $/ 912043517$ ? accountid $=8424$

Rajan, B. (2015). Faith memes: An analysis of authority as reflected in the social media of Churches in New Delhi. Interdisciplinary Journal of Research on Religion, 11(13). http:// www.religjournal.com/ articles/article_view.php?id=104

Rajan, B. (2016). Minority representation in 'The Digital': narrative from Christian communities in Delhi. TransMission: The Journal of Film and Media Studies, 1(1), 21-36.

Rajan, B., \& Sarkar, S. (2017). Emerging digital Church in India: A study of WhatsApp communication in Churches. In S. Kar (Ed.), Religion, society and culture (pp. 125-136). Kolkata: Monoshakti.

Rajan, B., \& Vaz, E. (2018). Sacred texting: a study on social media language trends in New Delhi and Bengaluru Churches. Amity Journal of Media \& Communication Studies, 8(1), 24-35.

Terre Blanche, M., \& Durrheim, K. (1999). Research in practice. University of Cape Town Press, Cape Town.

Thomas, P. (2008). Strong religion, zealous media Christian fundamentalism and communication in India. Sage Publications, Thousand Oaks.

Turner, W. V. (1969). The ritual process: structure and anti-structure. Cornell University Press, New York.

Usunier, J. C., \& Stolz, J. (2014). Religions as brands: new perspectives on the marketization of religion and spirituality. Ashgate AHRC. Ashgate Publishing Group.

Venugopal, C. N. (1990). Reformist sects and the sociology of religion in India. Sociological Analysis, Special Presidential Issue Sociology of Religion: International Perspectives, 51, S77-S88.

White, R.A. (2007). The media, culture, and religion perspective: discovering a theory and methodology for studying media and religion. Communication Research Trends, 26(1), 1-3.

Yagnik, B. (2013, November 24). Irish took to Gujarat with missionary zeal. The Times of India. Retrieved from https:// timesofindia.indiatimes.com/city/ahmedabad/Irish-took-to-Gujarat-withmissionary-zeal/articleshow/26280446.cms

Weber, M. (1968). Economy and society: an outline of interpretive sociology. Bedminster Press, New York.

Weber, M. (1966). Sociology of religion. Methuen, London. 


\section{Appendix: Images Used in Analysis}

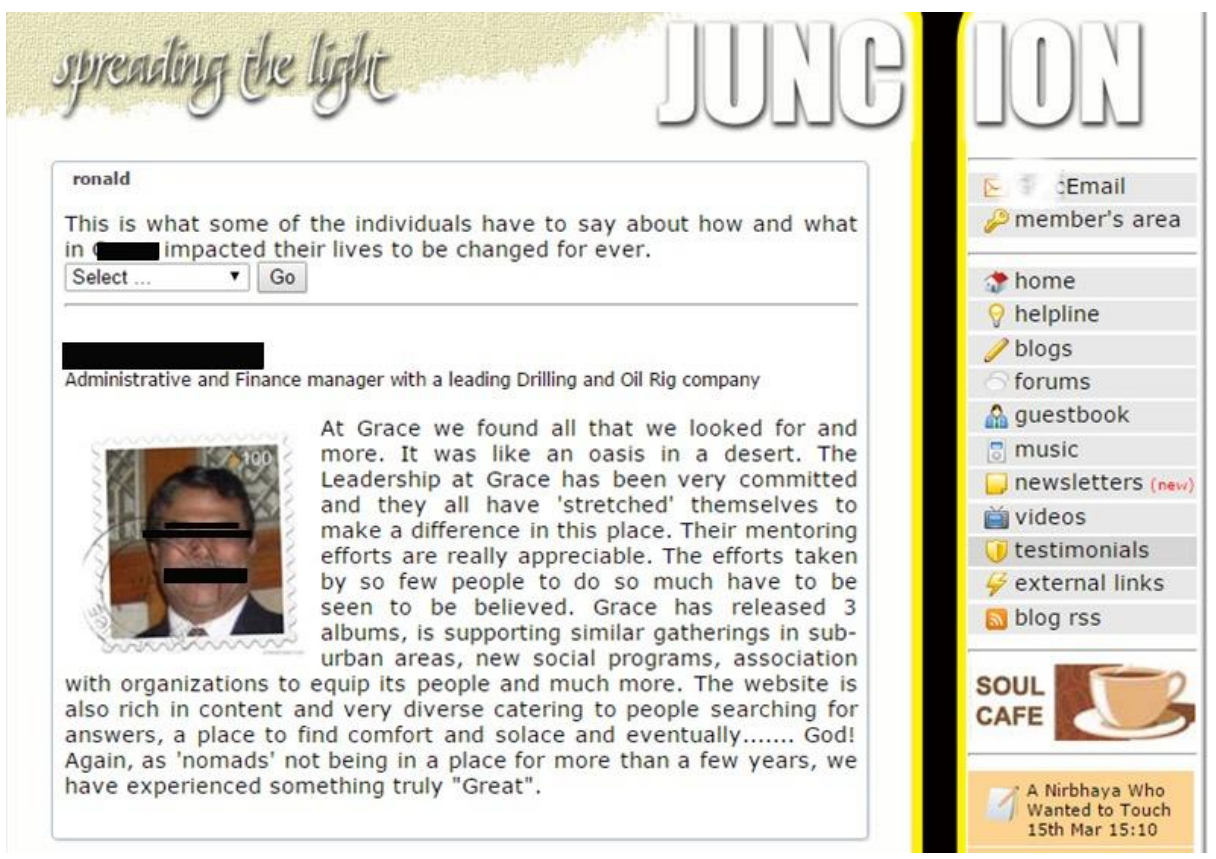

Fig 1: The Member Testimonials 
Rajan and Kundu Churching Online: A Study on Religious Authority

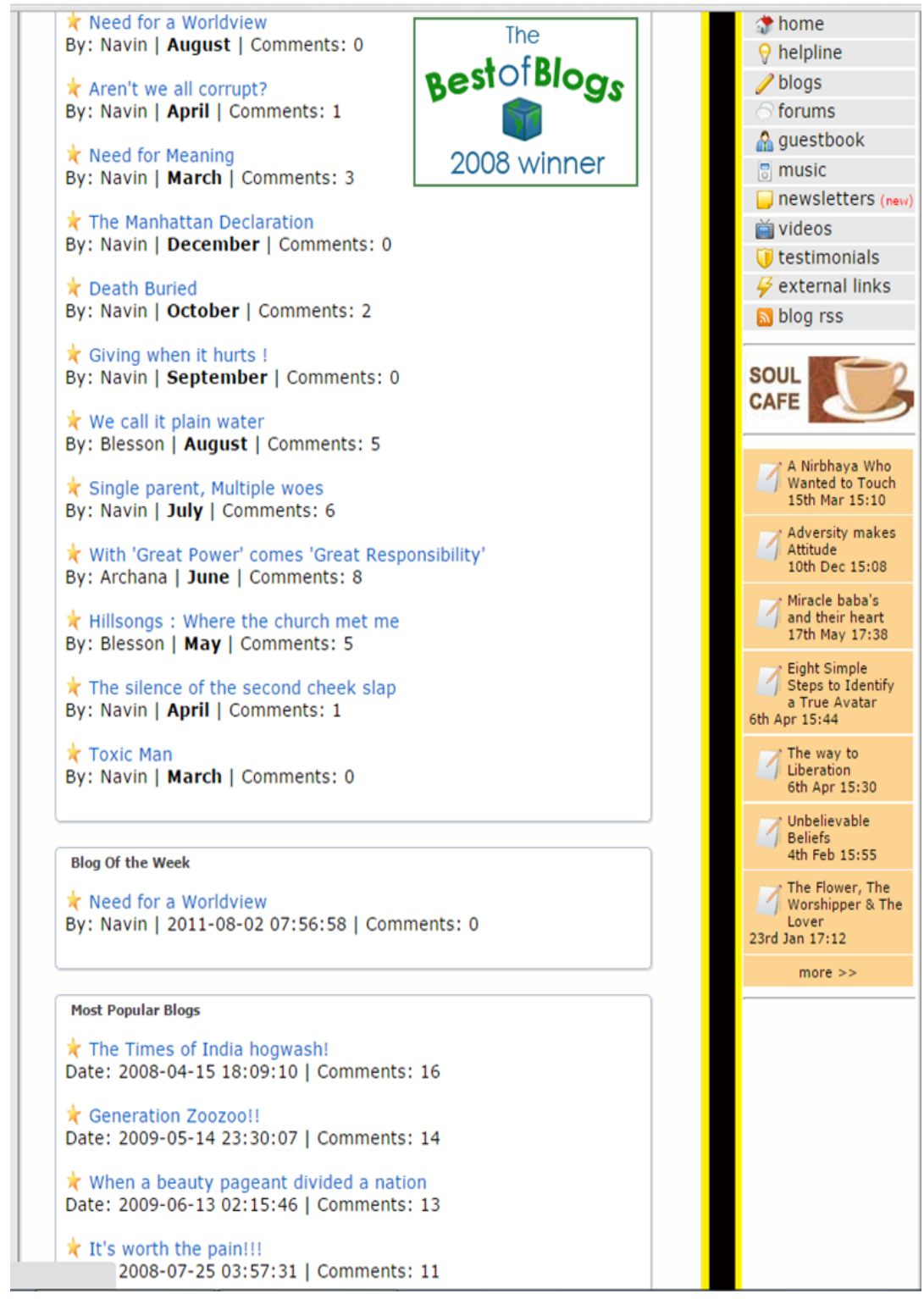

Fig 1.2: The AGF Website Allows Space for Members to Blog 


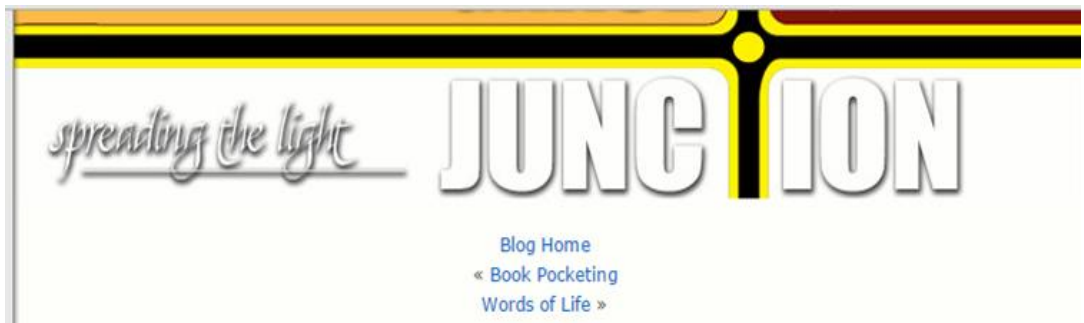

Generation Zoozoo!!

By: Geo (May 14th, 2009)

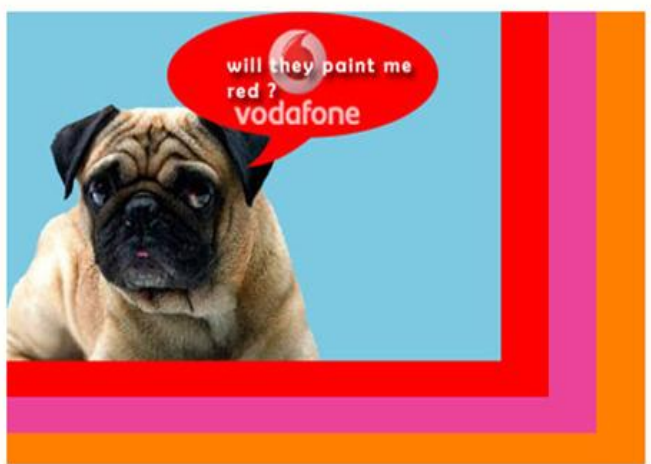

Finally Vodafone seems to have found the nemesis for the 'Pug". Hutch, the ex-name of Vodafone, was known for its pug, a dog that followed its owner everywhere, conveying the 'where ever you go, our network follows' punchline. The pug was such a hit that Hutch couldn't keep the pug out of any of its strategies and ads! I mean literally, whatever Hutch did, the pug followed! The pug tried to enter the Vodafone camp after Hutch was bought by Vodafone. However, Ogilvy \& Mather finally seem to have come to the rescue with a new $\operatorname{mascot}(s)$, thus paving the way for the last and final departure of the good old pug 'Chika'.

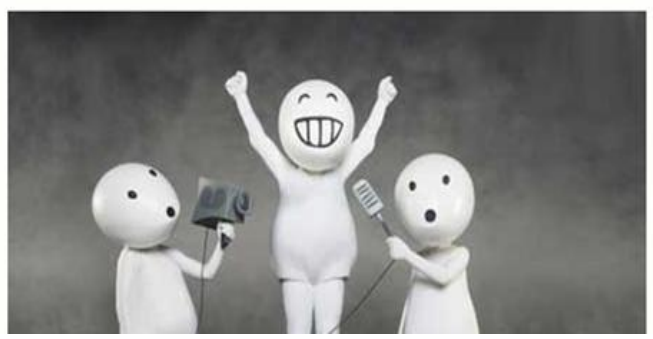

Fig 1.3: A Blog Entry Titled “Generation ZooZoo" on the AGF's Webpage 


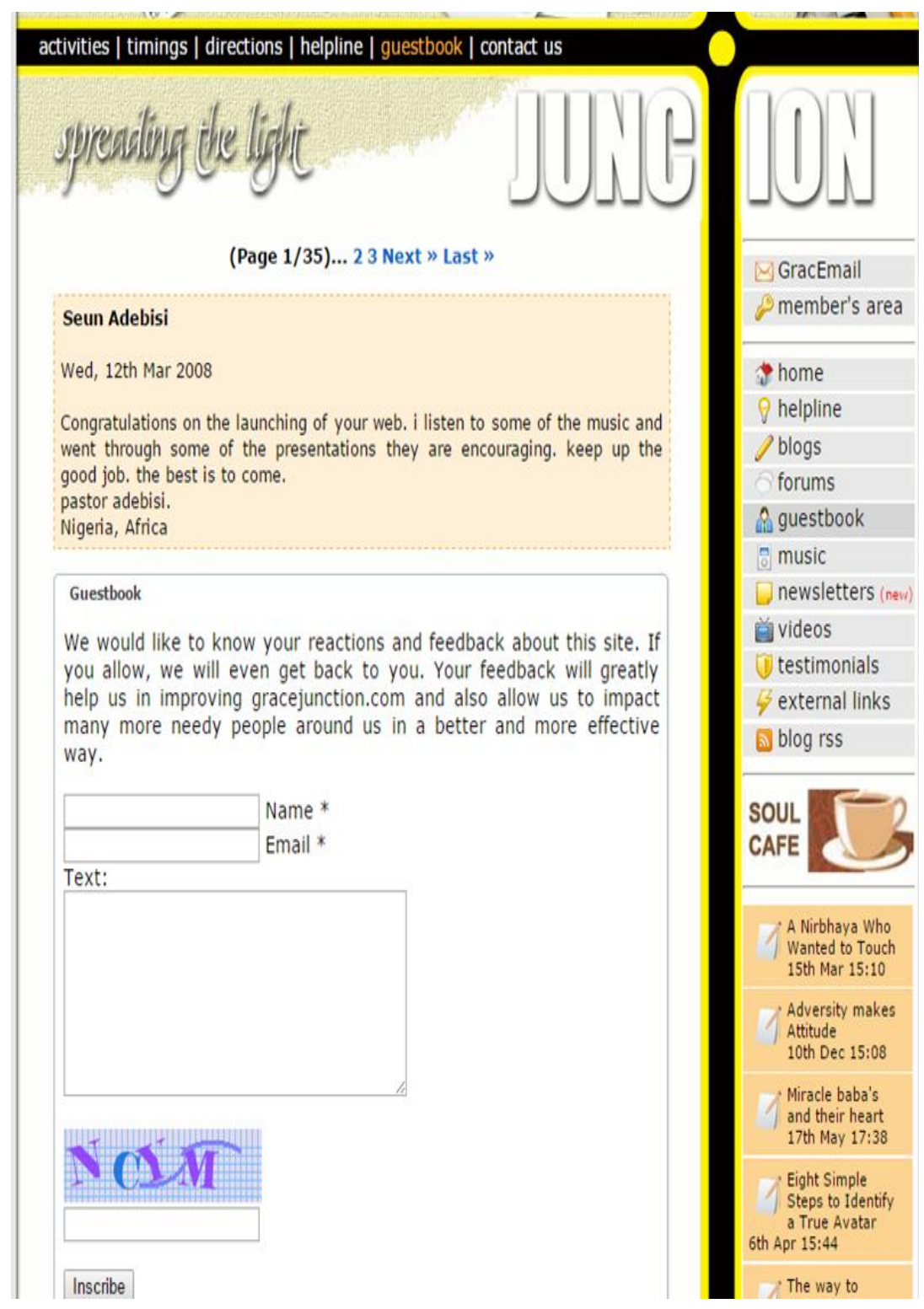

Fig 1.4: The Online Version of the Church Guest Books 
« First « Previous $1213 \ldots$ (Page 14/14)

Johns Says:

18th Sep 2008 03:22:09 AM

Performing Aarti:

I do not know the details, and I cannot see scriptural references to show that it is allowed, hence I cannot say it is right. Which is why I kept repeating again and again and again and.... "WITHIN SCRIPTURAL PRINCIPLES". If you cannot show from the Scriptures, taken in its true context, that your practice is sanctioned, then you are already on the wrong path.

I think we are again and again and again and... repeating ourselves: I did agree with you as you agreed with me and we agreed with each other, that culturalisation, contextualisation, identification, incamation, wharever you call it outside of Scriptural boundaries is a strict NO. ident there is a LOT of cultulisation, coutex in Scripture. I am speaking only about those steps. So, lets not go around in circles regarding this...

But, If you want to show that any of the methods or efforts I mentioned are unscriptural, then let us discuss that.

\section{Johns Says:}

18th Sep 2008 03:41:34 AM

Pooja,

In response to the next post:

I really do not get the feeling that either of us is in here to 'discuss' the point. But to just find loopholes in the other's point,

(even if it is easily understandable by putting a little thought or reading a few previous posts) and create an argument. I want to refrain from doing that.

All the points I posted are in direct response to your posts. If you are having such a big problem in relating to your own posts, I can, in future, post your comments first, and then my reply to those. I avoid that because the posts become unnecessarily long.

My point of discussing in the forum is ALWAYS that we leam from each other, which is why, when others bring in a point which $i$ appreciate, $i$ try to acknowledge it. But, if we are slowly starting to change it into a war of words, then we do not serve the purpose. Again, as I had mentioned to Geo earlier, I am a master at arguing! I can go on till Kingdom come, but then, we both have a lot of better things to do before Kingdom comes, let us both get busy doing that.

I can see that you find it extremely difficult to understand my contradictory posts, hence let us nive some rest to your pretty grey cells and mine, and use it for better purposes. For, I do not see

Fig 1.5: Online Forums for Members to Engage in Discussions 
Rajan and Kundu Churching Online: A Study on Religious Authority

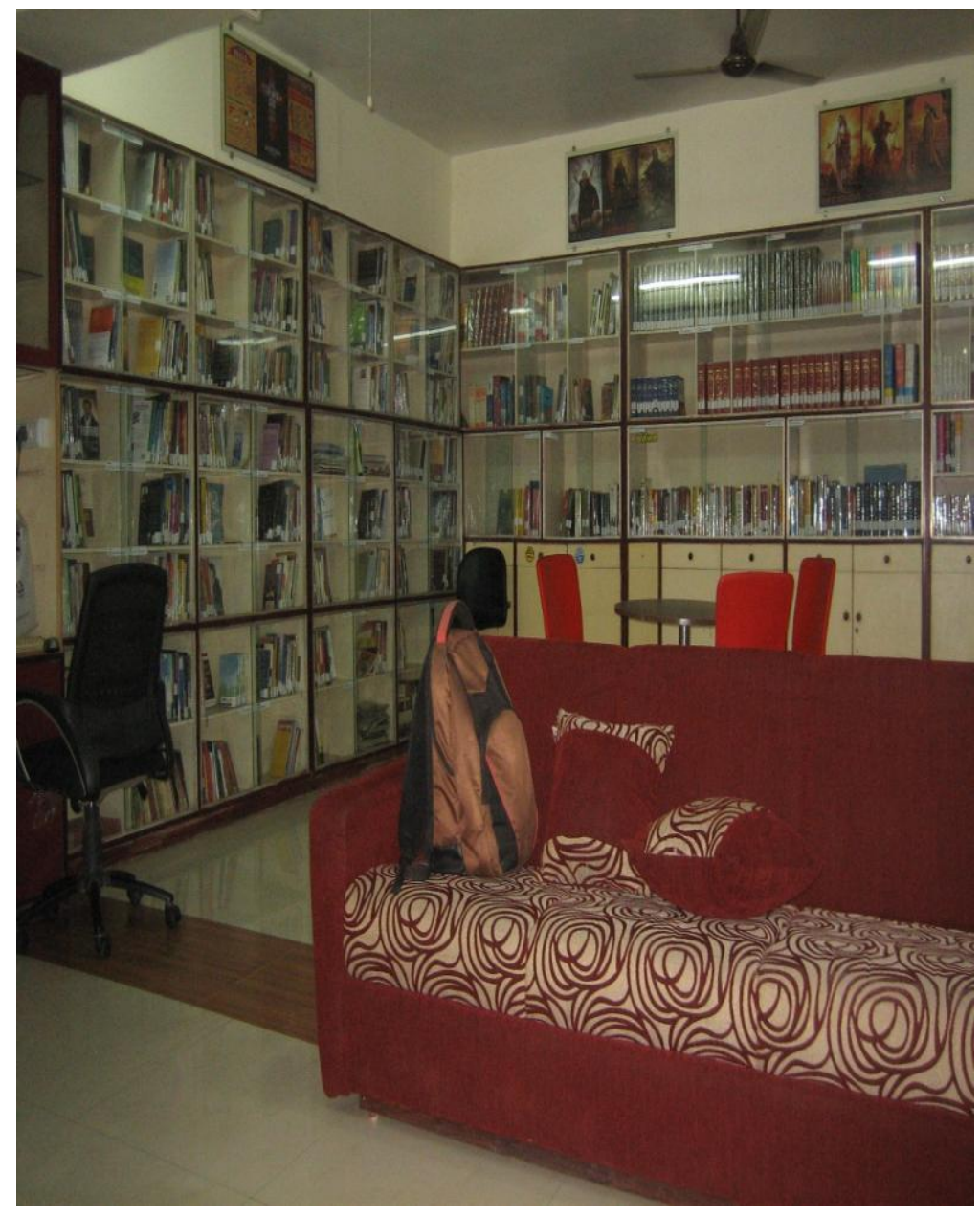

Fig 1.6: A Section of the Church's Offline, Physical Space 
This service is being rendered "absolutely free of cost". There are no hidden

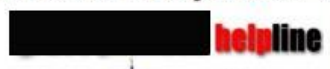
charges, no conditions. You don't have to reveal your identity or even your true email to get our help. Just fill in the form below that let's us know your problem/issue or struggle. This form will shoot an email to the concerned and qualified people and they will get in touch with you on the email you have provided and try their level best to help you.

house

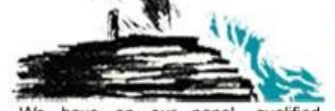

No, the contents of the form that you fill will not be displayed on the site.

We do not guarantee solutions. We are trying to help and we just want you to know that you don't have to feel lonely and We have on our panel, qualified defeated. We are there to stand by you as psychologists and counselors to far as we can. It's not yet time to give up address your concerns and issues. This on living, no, not yet to give up on life.

service is absolutely voluntary and free.

Please spread the word and make the Better times are ahead. most of this helpline.

Name / Nick Name / Alias *

Your Email *

Location (City, Country)*

Brief title for your concern

Description of your concern *

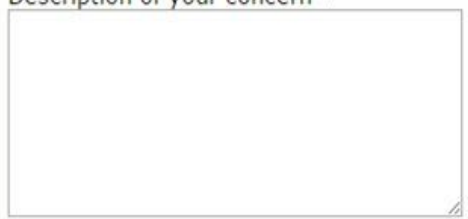

Deadline for help (dd/mm/yy)

Antispam measures: Please insert the letter and number combination into the text field before submitting the request.
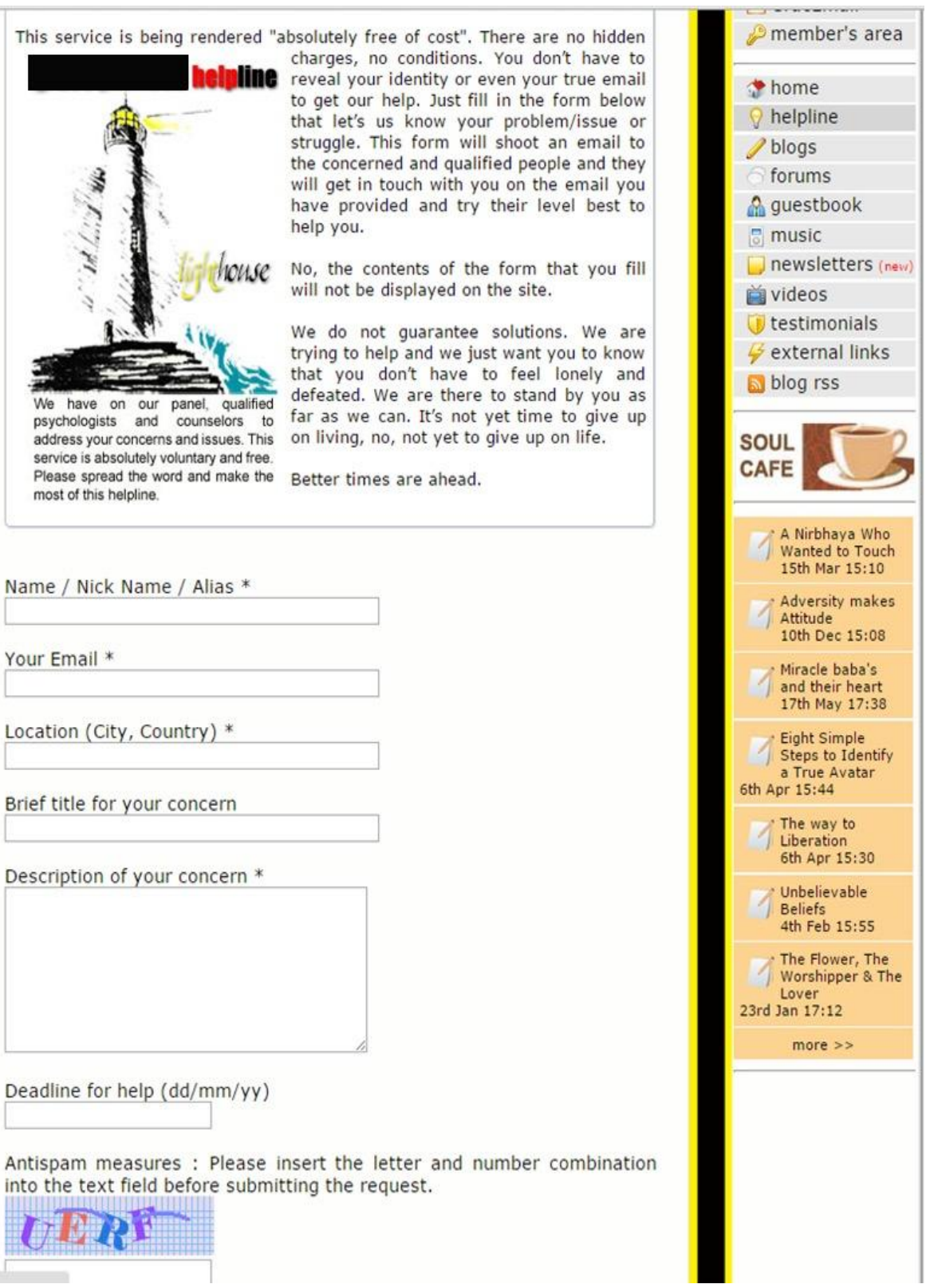

Fig 1.7: Free Helpline Service for Members Undergoing Personal Struggles 
Rajan and Kundu Churching Online: A Study on Religious Authority

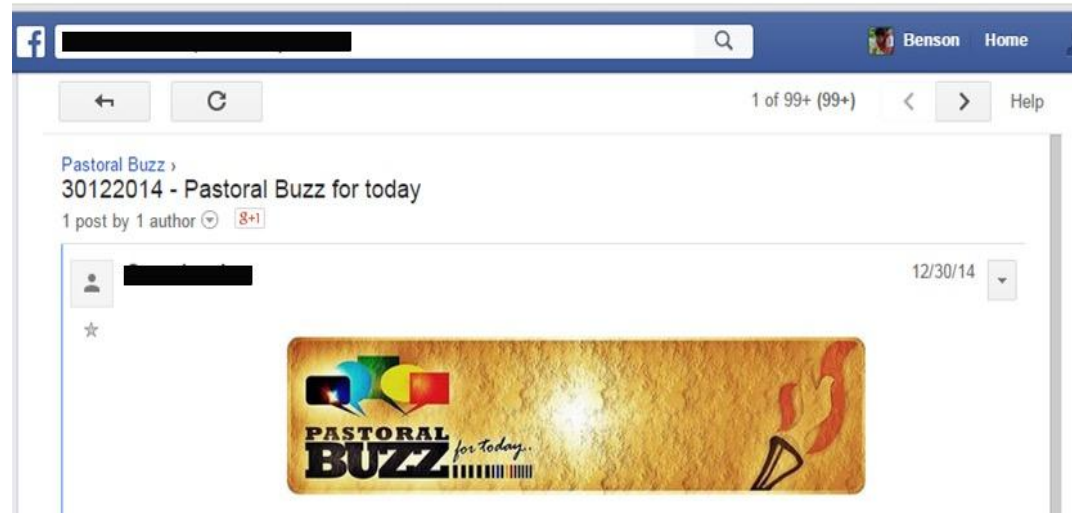

Thanksgiving Can Raise The Dead

John 11:41-42

And Jesus lifted up His eyes and said, "Father, I thank You that You have heard Me. And I know that You always hear Me...

After Jesus had said these words, He cried with a loud voice, "Lazarus, come forth!" And the man who had been dead for four days came out of his tomb!

This is one of the greatest miracles that Jesus performed. Lazarus had been dead for four days when Jesus raised him to life. Wouldn't you agree that death is indeed an extreme problem? Having no money in the bank, being sick and losing your job, bad as they are, are not as bad as being dead!

But what I want you to see is this: If Jesus, in the most extreme of problems, shows us that the solution is still, "Father, I thank You," then how much more should we thank God in the midst of the less serious problems we face. If thanksgiving can raise the dead, then let us give thanks in spite of the negative circumstances and we will see victory.

Unfortunately, we tend to do the opposite - murmur and complain. But murmuring and complaining only magnify the problem. Thanksgiving, on the other hand, is the language of faith which pleases God. I am not saying that we give thanks for the problems we have. No, we thank God that $\mathrm{He}$ is our answer and that He has already given every blessing to us. (Ephesians 1:3)

Thank fand for the little unu have and it will multinlu lecus thanked Hic Father for the five harlev Inaves and twn small fich

Fig 1.8: Dissemination of Devotional Content via Pastoral Buzz for Today 


\section{John Joseph Fri, 30 $30^{\text {th }}$ Dec 2011}

Wow! What a creative website. There is so much of info. I am amazed to see how creative you all are. Your CD Shukarya was a hit in our church this christmas. We did a whole play on Kuch Pal Hai. We took your song Prabhu tere aane sey as our theme carol song. You guys are a great blessing to us. Keep up the good work.

\section{Leo Raja Mon, 30 $30^{\text {th }}$ May 2011}

Hello guys, I would love to get your albums but how do I get them in INR. I am at Pondicherry India spreading the word to hindi speaking people (mostly migrant labourers) around here. Admin: You can send you address to admin@gracejunction.com and the albums will be sent to you by VPP.

\section{Ashish Randive Wed 30 ${ }^{\text {th }}$ Mar 2011}

Dear, Pastor Praise God, I was just surfing net...got ur website i would like to know bout ur chrch...

\section{Arun Michael Mon, 17 Mar 2008}

Congratulation on your website. I just like it's feel and look and what not. I also know that the blogs on this site will touch thousands upon thousands. May you be blessed as Jesus is glorified in and through all you do.

\section{Senu Adebisi Wed 12 Mar 2008}

Congratulations on the launching of your web. i listen to some of the music and went through some of the presentations they are encouraging. keep up the good job. the best is to come. pastor adebisi. Nigeria, Africa

\section{Deepak Wasley Tue, $23^{\text {rd }}$ Oct 2012}

Praise the Lord!

You Guys are doing Superb job! Keep it Up.

GOD BLESS YOU!

Deepak Wasley

Fig 1.9: Guestbook Entries Highlighting the Translocal Impact of the AGF and its Website 


\section{Endnotes}

[1] Assemblies of God Fellowship works as a global franchise which was established in the United States of America as a protestant Pentecostal movement in 1914. Its mission and vision originated in America and it is this model that has now been adopted globally.

[2] Sri Sri Ravi Shankar's Art of Living has a website, as well as social media presence on Instagram and Facebook. They also broadcast content on their YouTube channel supported by apps such as 'The Art of living' and 'Sri Sri' app. Other organisations that follow a similar model include Global Peace Foundation, Kopimism, Nation of Islam, Hanuman Foundation.

[3] The authors have assessed the study in a manner where the church's website and its content are kept confidential due to perceived threats from extremist organisations. Therefore, the name of the Church has been changed to the AGF in consent with the church authorities to prevent identification of the Church.

[4] Members of the AGF form 'cell groups' in Ahmedabad for a weekly Bible study. This is organised according to geographical convenience that breaks the members of the church into small clusters to meet once a week before the common Sunday meeting.

[5] According to the Hartford Institute for Religion Research, a "Megachurch" is defined as a very large, mostly Protestant congregation that is characterised by the following organisational, demographic, and leadership criteria:

(i) Massive numbers of persons in attendance

(ii) A charismatic, authoritative senior minister

(iii) A very active seven-day-a-week congregational community

(iv) A multitude of social and outreach ministries, and a complex differentiated organisational structure" (King, 2010).

[6] Their free helpline service, for example, allows individuals, experiencing personal struggles, to seek help through the virtual platform (Fig 1.7). The church has invested significantly in making qualified psychologists available to those in need. 